\title{
A globális városok térkapcsolatának vizsgálata légiközlekedési adatok felhasználásával
}

\section{Mapping the spatial relationship of global cities using air traffic data}

\author{
DUDÁS GÁBOR, PERNYÉSZ PÉTER
}

KULCSSZAVAK: gazdasági távolság, világváros, légi közlekedés, GIS

ABSZTRAKT: A globalizációs folyamatok, a közlekedési és kommunikációs infrastruktúrák fejlődése jelentős mértékben átalakította az emberek mobilitásának, az áruk szállításának és az információ áramlásának földrajzi és időbeli korlátait, elősegítve ezzel a világvárosok gazdasági kapcsolatainak egyre szorosabbá válását. Habár a technológiai innovációk következtében a földrajzi távolság fogalma új dimenzióba került, a gazdasági távolság és az elérhetőség szerepe egyre jobban felértékelődik.

Ezen tanulmány célja egy lehetséges módszer bemutatása a világvárosok közötti gazdasági távolság mérésére és a változások tematikus térképeken való ábrázolására. A gazdasági távolság meghatározására egyedi módszertant dolgoztunk ki, amelynek segítségével légiközlekedési adatok felhasználásával határoztuk meg a három globális város, London, New York, Tokió és a többi világváros közötti gazdasági távolságot és elérhetőséget, majd az eredményeinket hagyományos és GIS-alapú térképezési technikák felhasználásával vizualizáltuk.

KEYWORDS: economic distance, world city, air transport, GIS based mapping

ABSTRACT: Recent trends in global economic and transport and communication infrastructures have had a profound impact on the spatial organisation of the world city network. The development of transport infrastructure, especially air transport, has substantially decreased the geographic and temporal constraints of moving people, goods and information. It fostered the economic relationships between world cities. Although the "tyranny" of physical distance have been reduced by technological innovations of the transport industry, the emerging concept of "economic distance" can be observed.

The purpose of our research was to introduce a new method to measure the economic distance and accessibility between world cities using air traffic data. In our study the main question was what kind of spatial pattern stands out in the case of three hub cities (London, New York, Tokyo), if we take into consideration the economic distance instead of the geographical distance as a basis of a space forming factor. Besides we wanted to find out how accessibility of certain areas changes from the aspect of air transport.

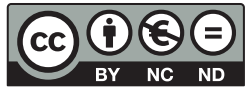


In our analysis we developed a database for a large number of leading world cities that included criteria such as cost, distance, flight duration and the number of airline transfers. We developed a unique method to calculate the economic distance between selected cities, and the collected global airline data are mapped using conventional and GIS based mapping and analysis techniques. Finally, we arrived at several thematic maps which represent the economic distance of London, New York and Tokyo in relation to each other.

Our study shows that air traffic data can provide an appropriate framework for measuring economic distance and analysing accessibility. According to our study, London exhibits the best economic distance values among the three hub cities; the second place goes to New York with some favourable positive shifts, while in the case of Tokyo negative tendencies are manifest, while several other world cities show significant negative changes.

In conclusion, we can state that the analysis of the economic distances of the three hub cities reveals different characteristics of the regions. London maintains strong relationships with the economic core regions, so these cities show a noticeable positive shift. Meanwhile in continental Europe, negative shifts towards the Economic Threshold Line (ETL) are dominating. Regarding all the regions, New York shows a mixed structure, whereas the cities of the Far East show a positive shift. Similarly to London, a positive distance from ETL is to be found also on the American continent. Tokyo possesses the weakest connections as none of the core regions is "getting closer", but significant connections remained with the important North American world cities. The air accessibility maps do not show striking regional differences but the good accessibility of the core regions is clearly verified.

\section{Bevezetés}

Az egyének utazásai, az áruszállítás, az információ továbbítása mindig is alapvető alkotóelemei voltak az emberi társadalomnak. A jelenkori gazdasági folyamatok, a közlekedési és kommunikációs infrastruktúrák fejlődése jelentős mértékben hozzájárultak az egyének növekvő mobilitásához és az egyes térségek elérhetőségének javulásához (Rodrigue et al. 2006), mindezek következtében a távolság fogalma is új dimenzióba került. A földrajzi távolság - mint a gazdasági és a társadalmi életet befolyásoló tényező - funkciója átalakulóban van, és egyre csökkenő szereppel bír (Cséfalvay 2004), az egyre gyorsabb és olcsóbb közlekedési eszközök elterjedésének köszönhetően.

Ennek következtében azonban sokakban felmerülhet a kérdés, hogy a „térzsugorító technológiák" elterjedésének és a távolságfogalom átértékelődésének következtében valójában milyen messze is van „A” ponttól „B” pont? Mennyi ideig tart az utazásunk e két pont között? Mennyibe kerül ez az utazás? Ezekre a kérdésekre gazdaságföldrajzi és regionális gazdaságtani elemzésekben találhatjuk meg a választ, hiszen ezeken a szakterületeken a földrajzi távolság helyébe gyakran kerül az adott távolság megtételéhez szükséges idő (időtávolság), valamint a szállítási költség (költségtávolság) (Nemes Nagy 2009).

Ennek a térbeli „átstruktúrálódási” folyamatnak a vizsgálatára a centrumtérségekben elhelyezkedő világvárosok, globális városok ${ }^{1}$ és globális hálóza- 
taik (world city network), valamint a légiközlekedési adatok nyújthatnak megfelelő elemzési keretet. A városhierarchia csúcsán elhelyezkedő városok mint a globális közlekedési hálózatok csomópontjai és mint a gazdasági élet fő centrumai vezérlik a gazdasági erőforrások, az emberek, a tőke, az áruk és az információk áramlását. Ezen globális áramlási rendszerek működtetéséhez a légi közlekedés biztosítja az egyetlen, az egész világot behálózó közlekedési hálózatot (ATAG 2008). Ennek köszönhetően az egyes térségek légiközlekedési kapcsolatai nagymértékben befolyásolják az adott térség elérhetőségét (Short et al. 1996) és a globális gazdaságba való beágyazódottságát, hiszen a fejlett légiközlekedési kapcsolatok lehetővé teszik a nagy távolságok gyors áthidalását, hozzájárulnak az emberi mobilitás növekedéséhez, emellett elősegítik a rövid és hosszú távú migrációs áramlások megvalósulását (Button, Vega 2008). Mindemellett meghatározó szerepet töltenek be a globális gazdasági és üzleti kapcsolatok müködtetésében (Short et al. 1996), valamint a világ turisztikai forgalmának lebonyolításában (ATAG 2008) is.

Kutatásunk célja egy új módszer alkalmazása, amely légiforgalmi adatok segítségével vizsgálja a világvárosok közötti gazdasági távolságot és az egyes centrumok elérhetőségét. A gazdasági távolság fogalmának használata azonban magyarázatot igényel. A nemzetközi szakirodalom alapján a költségtér, a költségtávolság, illetve a gazdasági tér és a gazdasági távolság szinonim fogalmak (Pirie 2009), azonban a magyar tudományos életben elfogadott költségtávolság- és költségtér-definíción (Dusek, Szalkai 2006, Nemes Nagy 2009) a mi gazdaságitávolság-interpretációnk túlmutat. A tanulmányban használt gazdasági távolság kiszámítási módját tekintve a költségtávolságnak felel meg, azonban elméleti síkon vizsgálva mi nemcsak két pont közötti szállítási költséget értünk rajta, hanem a térbeli áramlások egyik mérőszámát is, ami túlnyúlik a fizikai távolságok költségekkel történő mérésén ${ }^{2}$. Úgy véljük ugyanis, hogy a légi közlekedésben elfoglalt hely a városoknak a globális áramlásokban, a légitársaságok üzletpolitikájában, annak „absztrakt tereiben” (conceived space) (Lefebvre 1991) betöltött szerepét tükrözi. Úgy is fogalmazhatunk, hogy a légiközlekedési csomóponti szerep - illetve a kívül maradás ezen áramlási rendszereken - egyszerre terméke és alakítója a gazdaság „hatalmi geometriájának" (Massey 1991), és ennek térbeli leképezésére a légiközlekedési adatokból számolt gazdaságitávolság-értékek nyújtanak megfelelő keretet.

Ennek nyomán tanulmányunkban arra a kérdésre keressük a választ, hogy a globális városhierarchia csúcsán elhelyezkedő London, New York és Tokió esetében milyen új térstruktúra rajzolódik ki, ha a földrajzi távolság helyett a gazdasági távolságot vesszük alapul mint téralkotó tényezőt, és hogyan változik az egyes térségek elérhetősége a légi közlekedés szemszögéből.

Tanulmányunk első felében röviden összefoglaljuk a légiközlekedési adatok használhatóságát a világváros-kutatásban, valamint ismertetjük a kutatás folyamán alkalmazott adatgyüijtési, feldolgozási és ábrázolási módszereket. Kutatásunk második felében a változások vizsgálatához készített tematikus és 
izotérképek segítségével elemezzük és összehasonlítjuk a már Sassen (1991) által is globális városokként definiált London, New York és Tokió más világvárosokhoz való gazdasági távolságát és elérhetőségét.

\section{Légiközlekedési adatok használata a világváros-kutatásban}

A világváros-kutatás előrehaladtával egyre nyilvánvalóbbá válik, hogy a városok irányítófunkcióiknak fontossága és gazdasági erejük valamilyen formában összefüggésbe hozható reptéri infrastruktúrájukkal és az ott lebonyolított utasforgalom mértékével (Derudder, Witlox 2008), ebből kifolyólag a légi közlekedés megfelelő elemzési keretet biztosíthat a világvárosok közötti kapcsolatok és hálózatok elemzésére (Cattan 1995, Knox, Taylor 1995, Short et al. 1996). Ezt a megállapítást támasztja alá Keeling (1995) kutatása is, amelyben a légiközlekedési statisztikák használatának alkalmazhatóságát hangsúlyozza a világvárosok hálózatának vizsgálatában, és meghatároz öt alapvető indokot ennek alátámasztására:

- A globális légiközlekedési áramlások számbavétele egyike azon kevés statisztikáknak, amelyek rendelkezésünkre állnak a városok közötti transznacionális áramlások vizsgálatára.

- A légiközlekedési hálózat és a repülötéri infrastruktúra a világvárosok közötti kapcsolatok legláthatóbb megnyilvánulása.

- A globális telekommunikációs forradalom ellenére az üzleti életben még mindig magas a személyes kapcsolatok iránti igény (ezt megkönnyíti a légi közlekedés).

- A légi közlekedés a városok közötti utazások legegyszerübb módja a transznacionális tőkésosztály, a bevándorlók, a turisták és a nagy értékủ áruk szállítása esetén is.

- A légiközlekedési kapcsolatok a világvárosi státusra törekvés fontos elemét képezik.

Keeling (1995) után számos kutató vizsgálta a világváros-hálózatot légiközlekedési adatok segítségével. Smith és Timberlake $(2001,2002)$ a fó repülőterek utasforgalma alapján határozta meg a „legközpontibbnak" tartott világvárosokat, míg Matsumoto $(2004,2007)$ tanulmányaiban az utas- és áruforgalom mellett már egyéb tényezőket is számításba vett (GDP, népességszám, távolság és számos dummy változó3), és ezek segítségével alkotta meg a világvárosok és a nemzetközi légiközlekedési hálózatok kapcsolatrendszerének sematikus leképezését. Zook és Brunn $(2004,2006)$ másfajta szemléletmódot alkalmaztak: nem utasforgalmi adatokat használva, hanem egy újszerü megközelítésből kiindulva a repülőjegyár, a távolság, a repülési idő és a napi kapcsolatok számának segítségével próbálták meghatározni a globális városhierarchiában bekövetkező változásokat. 
Véleményünk szerint a légiközlekedési statisztikák alkalmazásának a korábbi tanulmányokhoz képest legfontosabb előnye, hogy a vizsgálatokat konkrét városok közötti kapcsolatadatokra, azaz konkrét városok közötti áramlásokra alapozhatjuk. Azonban ezen adatok használatának is megvan a maga kritikája: a nemzetközi szakirodalomban három alapvető hiányosságot állapítottak meg alkalmazhatóságukat illetően (Derudder et al. 2008, Derudder, Witlox 2005, 2008). Az első esetben az induló- és érkező-repülőtéri adatok hiánya (lack of origin-destination data) figyelhető meg, ami torzító eredményeket adhat, túlbecsülheti a légiközlekedési csomópontként (hub) funkcionáló városok (mint például Amszterdam vagy Frankfurt) szerepét, hiszen ezeken a városokon keresztül áramlik a légi utasforgalom döntő többsége, így ezek felülreprezentáltak lehetnek, amire példaként szolgálhat Keeling (1995) kutatása. A második probléma, hogy a legtöbb légiközlekedési statisztika csak nemzetközi légiforgalmi kapcsolatok adatait tartalmazza, így - amint Rimmer (1998) kutatása esetében is megfigyelhető - olyan fontos kapcsolatok maradtak ki az elemzésből, mint például a Los Angeles-New York vagy a Chicago-New York várospár, így az általa megalkotott kapcsolatrendszer az USA világvárosait torzítva ábrázolja (Derudder, Witlox 2008). A harmadik esetben pedig az okoz problémát, hogy a legtöbb adatbázis általános áramlási adatokat tartalmaz, így - amint Kunzmann (1998) vizsgálata is mutatja - olyan városok is bekerülhetnek a világvárosok közé az utasforgalmi adatok alapján, mint Palma de Mallorca, amely világvárosi funkciókkal nem rendelkezik, viszont jelentős turisztikai desztináció, ami jelentős utasforgalmat generál.

Mérlegelve a szakirodalmi előzményeket, elemzésünk szempontjából a Zook és Brunn $(2004,2006)$ által megalkotott szemléletmódot találtuk a legjobban alkalmazhatónak. Ennek nyomán kutatásunkat nem utasforgalmi adatokra alapoztuk, hanem internetes adatgyüjtés során az egyes városok közötti lekérdezett légiközlekedési adatokra (repülőjegyár, utazási idő stb.). Az adatok segítségével tematikus és izotérképeket szerkesztettünk, amelyek a globális és világvárosok közötti gazdasági távolságot és elérhetőséget ábrázolták.

\section{Az alkalmazott módszerek}

Vizsgálatunkat az elemzési egységek és a kitüntetett városok definiálásával kezdtük (azon városokéval, amelyek a repülési adatok lekérdezésénél kiindulási repülőtérként funkcionáltak).

Első lépésként létrehoztunk egy 175 világvárost tartalmazó halmazt. Ezt követően a nemzetközi szakirodalom (Beaverstock et al. 1999, GAWC 2008) és statisztikai adatok (ACI 2006, www.citypopulation.de) felhasználásával meghatároztuk az elemzésünk szempontjából legfontosabb 100-at. A rangsoroláshoz komplex mutatórendszert dolgoztunk ki, amelyben a világvárosok a népessé- 
gük, a világgazdaságban betöltött szerepük és a repülőtéri utasforgalmuk alapján szerepeltek. Minden egyes mutató esetében egy egységes „csökkenő” pontozási rendszert alkalmaztunk, amelyben az adott kategóriában legjelentősebb város 175, míg a rangsor alján szereplő város 1 pontot kapott. Az első mutató összeállításakor a városok agglomerációs népességét vettük figyelembe, amit a www.citypopulation.de oldalról szereztünk be (a 2010. 01. 01-es adatokat használtuk). A második mutató a városok globális gazdaságban betöltött szerepét reprezentálja, ehhez a Globalization and World Cities kutatóhálózata által elkészített világvárosbesorolást (GaWC 2008) alkalmaztuk, amely attól függően hierarchizálja a városokat, hogy milyen mértékben összpontosulnak bennük a gazdasági életet irányító funkciók. A harmadik mutatót az adott város repülőterének utasforgalma (ACI 2006) adta. Azokban a városokban, ahol több repülőtér is jelentős menetrend szerinti légi forgalmat bonyolít le, a repülőterek utasforgalmát összegeztük; például London esetében a város utasforgalmát a Heathrow-i, a Gatwick-i, a Stansted-i és a Luton-i repülőterek összesített forgalma adta. Így az elsődleges leválogatás fázisában az egyes városokhoz tartozó három mutatószámot összesítettük, és rangsorba állítottuk őket, aminek eredményeképpen megkaptuk 100 városnak azt a listáját, amely a további elemzésünk alapjául szolgált. A kiválasztott városok földrajzi megoszlása a következőképpen alakult: Európa - 32, Észak-Amerika - 23, Távol-Kelet - 22, Közép- és Dél-Amerika - 8, Afrika - 6, Közel-Kelet és DélnyugatÁzsia - 5, Óceánia - 4.

A kitüntetett városok meghatározásánál figyelembe vettük a korábbi szakirodalmat is (Zook, Brunn 2006), azonban mi a három gazdasági centrumtérség (Észak-Amerika, Nyugat-Európa, távol-keleti térség) 6-6 városának repülőterét választottuk kiindulási repülőterekként. Ennek megfelelően az adott régiókban legjobb mutatóval rendelkező városokat választottuk a százas listáról ${ }^{4}$.

A kutatás következő fázisában az adott várospárokhoz tartozó légiforgalmi adatokat kérdeztük le. Először a már meglévő repülőjegyár-adatbázisokat ${ }^{5}$ (Burghouwt et al. 2007) vizsgáltuk meg, azonban azt tapasztaltuk, hogy ezek a kutatók számára ingyenesen nem hozzáférhetőek, valamint nem tartalmaznak elegendő információt, és hiányosak is, így a hazai és nemzetközi szakirodalomban is elfogadott (Bilotkach 2010, Bilotkach, Pejcinovska 2009, Burghouwt et al. 2007, Csizmadia, Csuták 2004, Dobruszkes 2006, 2009, Hadnagy 2011, Zook, Brunn 2004, 2006) internetes adatgyüjtéshez folyamodtunk. A repülőjegyárakat a piacvezető internetes utazási iroda (ORBITZ) (Bilotkach 2010) honlapjáról kérdeztük le (www.orbitz.com). Az ORBITZ-ra nemcsak azért esett a választásunk, mert az egyik vezető online utazási iroda, és az egyik legnagyobb számítógépes foglalási rendszerrel van összeköttetésben (Worldspan) - emellett a külföldi szakirodalomban is használt repülőjegyár-adatbázis (Bilotkach 2010, Bilotkach, Pejcinovska 2009) -, hanem mert az előzetes összehasonlító lekérdezések alkalmával is az ORBITZ kezelőfelülete bizonyult a leginkább felhasználóbarátnak, és a webfelület információtartalma a legnagyobb volt a vizsgált rendszerek közül. 
Az adatok megszerzéséhez két adatfelvételt végeztünk előre meghatározott időben és időszakra vonatkozóan. A külföldi szakirodalom alapján (Dobruszkes 2009, Zook, Brunn 2004, 2006) a repülőjegyek minden esetben odavissza útra szóltak, és a felvételezés időpontjától egy hónappal előre következő hétfőtől hétfőig terjedő intervallumot foglalták magukba. Ennek nyomán az első lekérdezés 2010. február 1., 2., 3-án volt, a 2010. március 1-jei és március 8-ai napokra vonatkozott, míg a második adatfelvétel 2010. július 5., 6., 7-én volt, az 2010. augusztus 2-ai és augusztus 9-i napokra vonatkozott. A lekérdezett adatok tartalmazták a legolcsóbb (economy) repülöjegyárat ${ }^{6}$, a hozzá tartozó repülési időt, a kiinduló, átszálló és érkezési repülőtereket, valamint a legrövidebb utazási időhöz tartozó repülőjegyárakat is.

A lekérdezett adataink kezeléséhez, rendszerezéséhez, a városok közötti gazdasági távolság meghatározásához és a kapott értékek térképi megjelenítéséhez szükségünk volt egy térinformatikai rendszerre - választásunk az ESRI ArcGIS 9.3ra és moduljaira esett -, amellyel nagyméretű adattábláinkon kötegelt feldolgozást végezhettünk. Első lépésként a Google Earth adatbázisából lekérdeztük a kutatásban szereplő városok földrajzi koordinátáit, majd formátumukat átalakítottuk az általunk használt WGS84 vetületi rendszerhez, és ábrázoltuk őket az alaptérképünknek választott vektoros állományú világtérképen.

A városok térképi megjelenítése után a korábbi szakirodalomban használt módszertanon (Csizmadia, Csuták 2004, Zook, Brunn 2004, 2006) módosítva meghatároztuk a városok közötti gazdasági távolságot a repülőjegyár, a városok közötti földrajzi távolság és a térképi alaparányok felhasználásával. A három paraméter közül csak a repülőjegyár volt ismert számunkra, ezért definiáltuk a másik két paramétert is. A kiindulási repülőterek és a célállomások közötti földrajzi távolságokat, valamint a hozzájuk tartozó irányszögeket az ESRI ArcGIS 9.3. Geodesic Tools moduljával határoztuk meg a városkapcsolatok között. A harmadik paraméter, a térképi alaparány(ok) kiszámolásához szükségünk volt arra az információra, hogy mennyibe kerül $1 \mathrm{~km}$ repüloút "A" és „B" város között. Ezen értékek meghatározásánál figyelembe vettük, hogy a távolság növekedésével a repülőjegyárak nem egyenes arányban növekednek (Dicken 2007, Knowles 2006, Taaffe et al. 1996), ezért a torzító eredmények elkerülése végett négy távolságzónára számoltuk ki a térképi alaparányokat. Mivel a nemzetközi szakirodalom sem rendelkezik egységes kategorizálással a távolságzónákkal kapcsolatban, ezért megalkottuk saját besorolásunkat (1. táblázat).

A térképi alaparányok meghatározásához a teljes lekérdezés adatbázisát használtuk. Először földrajzi távolságuk alapján négy adatbázisba soroltuk az 1636 városkapcsolatot ${ }^{7}$ (1. táblázat). Emellett az adatbázisok a földrajzi távolságok mellett tartalmazták a két adatfelvétel repülőjegyárait is. A torzító eredmények elkerülése végett - hiszen a téli és a nyári időszak repülőjegyárai között nagy különbségek mutatkozhatnak (Dudás, Pernyész 2011a) - átlagoltuk a két lekérdezés repülőjegyárait. Ezután a négy adatbázis alapján megha- 
1. táblázat: Távolsági szintek a légi közlekedésben repülési idő és földrajzi távolság alapján

\begin{tabular}{lcc}
\hline \multicolumn{1}{c}{ Távolsági zóna } & Repülési idő, óra & Földrajzi távolság, km \\
\hline Rövid táv & $<3$ & $<2000$ \\
Középtáv & $3-6$ & $2001-4000$ \\
Hosszú táv & $6-12$ & $4001-9500$ \\
Ultra hosszú táv & $>12$ & $>9500$ \\
\hline
\end{tabular}

Forrás: saját szerkesztés.

tároztuk a négy távolságkategóriára a térképi alaparányokat. A folyamat első lépéseként adatbázisonként kiszámítottuk az átlagos távolságot, majd hasonló módon határoztuk meg az átlagos repülőjegyárakat is. A kapott átlagok felhasználásával kategóriánként kiszámoltuk az egyes távolságkategóriákhoz tartózó arányértékeket, így megkaptuk, hogy a rövid távon 0,256 USD-ba, középtávon 0,16 USD-ba, hosszú távon 0,14 USD-ba, míg ultra hosszú távon 0,122 USD-ba kerül egy kilométer megtétele. Az így kapott arányértékkel elosztva az adott városkapcsolatokhoz tartozó repülőjegyárat, megkaptuk a gazdasági távolságok értékét, vagyis azt, hogy az adott összegből milyen messzire tudtunk utazni.

A kiszámolt gazdasági távolságértékek segítségével megállapítottuk a célvárosok új helyének koordinátáit, és ábrázoltuk azokat a térképünkön. Az ESRI ArcGIS 9.3. Military Analyst Tools modulját használva a célvárosok helyét és a virtuális helyüket összekötöttük, és jól elkülönülő jelkulccsal ábrázoltuk a „közeledő” és „távolodó” városokat ${ }^{8}$. Térképünkön az általunk használt térképvetület következtében ezek a vonalak nem egyenesek, hanem görbék, mivel a földgömb vetülete van kiterítve a síkban.

Az elérhetőség ábrázolásához a geostatisztikában használt interpolációs eljárást, az úgynevezett „krígelést” alkalmaztuk, annyi különbséggel, hogy a pontok magasságértékei helyett a ponthoz tartozó repülőjegyárakat használtuk. Ez a módszer a megszokott interpolációs eljárásoknál sokkal pontosabb „árfelületet” eredményezett.

\section{Gazdasági távolság és elérhetőség a városhierarchia csúcsán elhelyezkedó városok között}

Kutatásunk során légiközlekedési adatok segítségével vizsgáltuk London, New York és Tokió gazdasági távolságát a legolcsóbb repülőjegyár és elérhetőség figyelembevételével, és az eredményeinket tematikus térképeken ábrázoltuk. 


\section{Gazdasági távolságok a globális városok és a világvárosok között}

Az elemzéshez kiválasztott világvárosok esetében eltérő területi struktúrák rajzolódnak ki a gazdasági távolság vizsgálatakor, azonban mindhárom esetben markáns térségi jellegzetességek is mutatkoznak. A legkedvezőbb képet London (1. ábra) esetében tapasztaljuk, ahol a nagyrégiók szintjének vizsgálata során pozitív területi mintázat körvonalazódik, aminek következtében Észak-Amerika és Ázsia városai közelebb helyezkednek el a térképen, mint földrajzi távolságuk indokolná. Dél-Amerika és Afrika városai vegyes képet mutatnak, míg a korábbi kutatásokhoz képest (Dudás, Pernyész 2011 a, 2011 b, Móricz, Dudás 2010) a differenciált térképi alaparányoknak köszönhetően Európában is vegyes térstruktúra rajzolódik ki. Észak-Amerikában a „közeledés” dominanciája csak az Egyesült Államok városainak sajátossága, a három kanadai világváros (Montreal, Toronto, Vancouver) távolabbra került a gazdaságitávolság-értékek alapján. Európában a kontinens közlekedés-földrajzi adottságai, valamint a légiközlekedési ágazatban egyre nagyobb szereppel bíró méretgazdaságossági megfontolások következtében - amelyek elsősorban a rövidebb távolságokon érvényesülnek - London esetében is körvonalazódik a gazdaságossági küszöb ${ }^{9}$ vonala - mint a korábbi kutatások esetében Budapestnél (Móricz, Dudás 2010) -, ami a brit fövárostól 700-750km sugarú köríven húzódik (2. ábra). Ennek következtében a gazdaságossági küszöbön belül elhelyezkedő városok gazdaságitávolság-értékei minden esetben meghaladják a földrajzi távolságuk értékét, míg a küszöbértéken kívüliek pozitív irányú elmozdulásokat mutatnak, mint például Moszkva, Athén vagy éppen Helsinki. Dél-Amerikában és Afrikában a kapuszerepet betöltő városok ${ }^{10}$ (Sao Paulo, Buenos Aires vagy Johannesburg) esetében figyelhetők meg hasonló pozitív értékek a gazdasági távolságok alakulásában.

A települési szintet vizsgálva (1. ábra) megállapítható, hogy három óceániai város: Sydney, Melbourne és Auckland mutatják a legjobb gazdaságitávolság-értékeket. Számításaink szerint Sydney földrajzi távolságának közel egyharmadával (5545 km-rel), Melbourne virtuálisan földrajzi távolságának közel egynegyedével (4750 km-rel), míg Auckland durván egyötödével (4002 km-rel) került közelebb Londonhoz. Őket követi a távol-keleti térség négy további világvárosa, Sanghaj, Bengaluru (Bangalore), Csennaj (Madras) és Jakarta átlagosan $3000 \mathrm{~km}$-es pozitív irányú elmozdulással. Ezek a folyamatok is hangsúlyozzák a régió egyre növekvő gazdasági szerepkörét, valamint az angol főváros és a távol-keleti térség között kialakult szoros gazdasági kapcsolatokat.

New York esetében (3. ábra) is hasonló tendenciák mutatkoznak, mint amilyeneket a brit főváros esetében tapasztalhattunk. Az ázsiai térség, valamint az európai kontinens városai gazdaságitávolság-értékeik alapján egyöntetűen közelebb helyezkednek az amerikai metropoliszhoz, mint földrajzi távolságuk indokolná. Londonnal ellentétben a differenciált térképi alaparány-értékeknek köszönhetően New York esetében nem rajzolódik ki mar- 


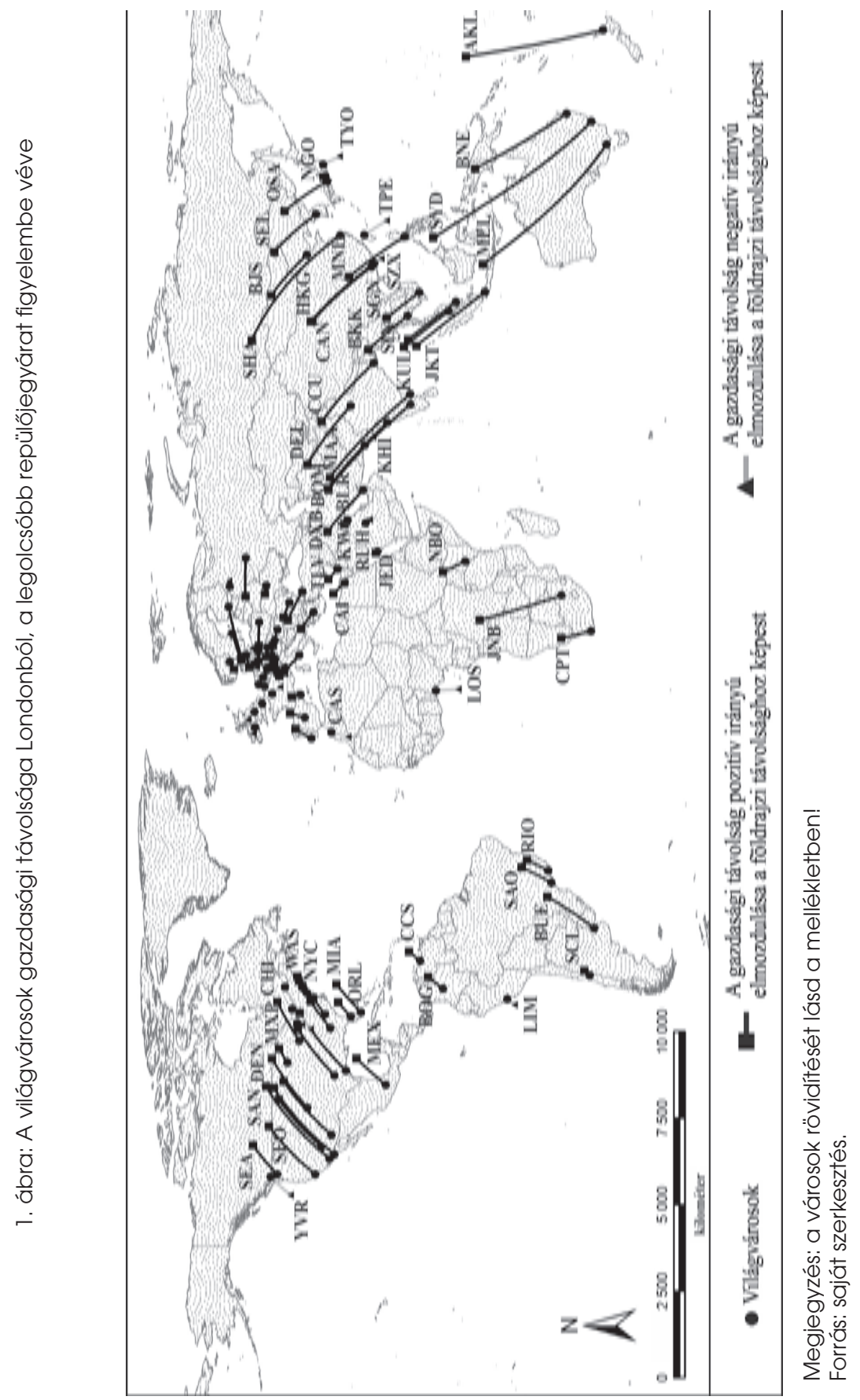




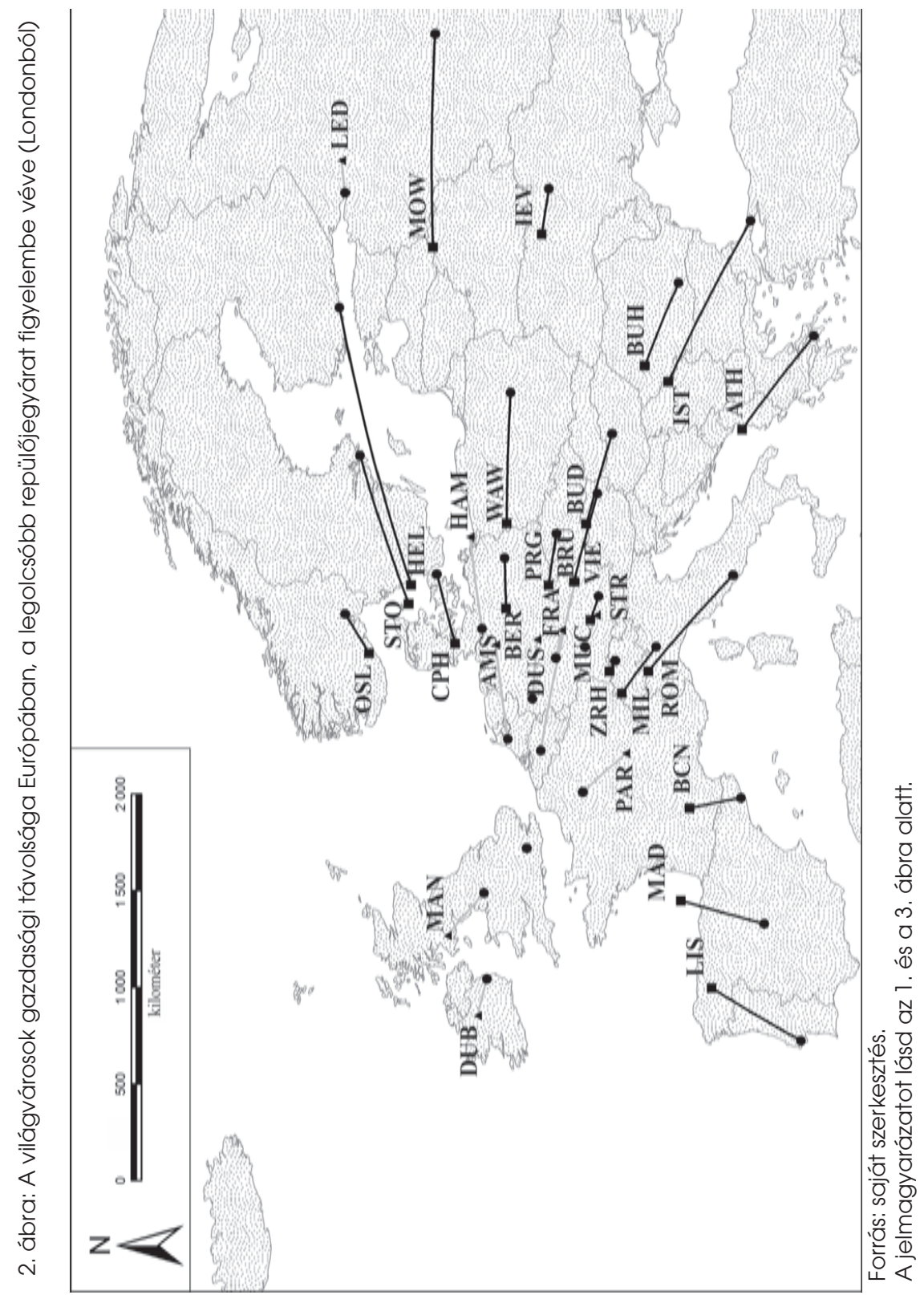




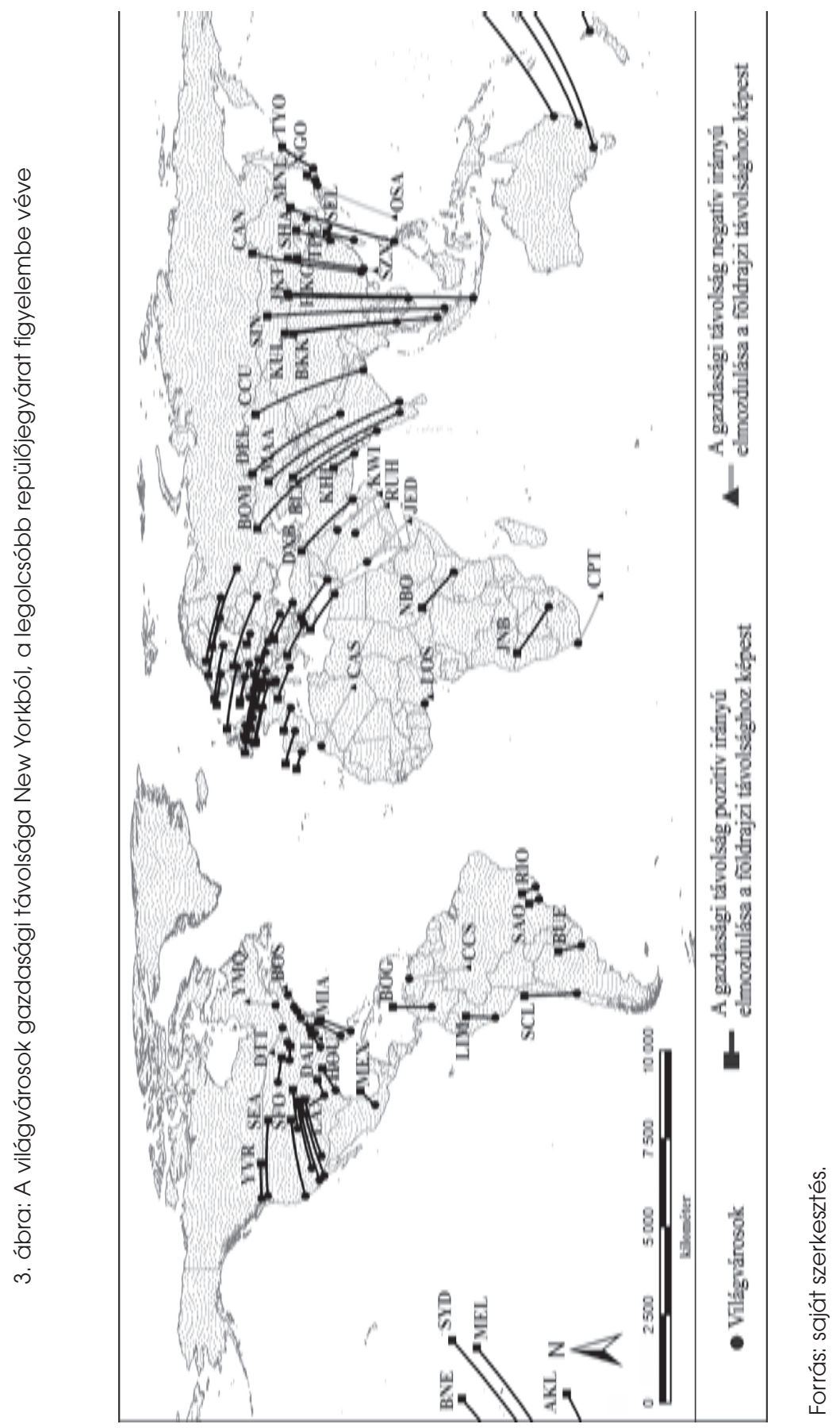


kánsan a kontinensen belüli gazdaságossági küszöb, azonban a városok dönt”̋ többsége így is pozitív irányú elmozdulást mutat, aminek következtében az észak-amerikai világvárosok egyik része 1600-1800 km-es köríven fekszik, míg a másik fele kb. 800 km-es távolságig mozdul el. Európában (4. ábra) Amszterdam, Budapest és Dublin kivételével az összes város közelebb került a földrajzi távolságához képest. Különbségek a „közeledés” mértékében fedezhetők fel. A legnagyobb pozitív irányú elmozdulással Kijev (1354 km), Moszkva (1351 km) és Frankfurt (1285 km) rendelkezik, míg a legkisebb mértékü torzulásokat Milánó $(46 \mathrm{~km})$, Stuttgart $(165 \mathrm{~km})$ és Manchester $(190 \mathrm{~km})$ mutatja.

A települési szintet New York szemszögéből vizsgálva (3. ábra) erőteljesen hangsúlyozódik New York kapuszerepe a távol-keleti térség irányába, hiszen míg a Londonból elérhető városok gazdasági távolságának pozitív irányban történő elmozdulásai közel azonos arányban oszlottak meg az amerikai és ázsiai kontinens világvárosai között, addig New York-nál egyértelműen az ázsiai városok dominanciája figyelhető meg. A legnagyobb „közeledést” mutató 20 város közül 18 a távol-keleti és óceániai térségben helyezkedik el, további kettő pedig az amerikai kontinens két nyugati parti nagyvárosa: Los Angeles és San Francisco. Ennek nyomán az amerikai világvárosból az ázsiai és óceániai térségbe a legkedvezőbb áron Melbournebe és Sydneybe utazhattunk, és eddig a két városig a gazdasági távolság több mint egyharmaddal csökkent a földrajzi távolsághoz viszonyítva.

Figyelemre méltó, hogy mindkét globális város esetében szoros gazdasági kapcsolatok rajzolódnak ki az újonnan iparosodó országok második hullámával (Thaiföld, Indonézia, Malajzia, Fülöp-szigetek (Jónás et al. 2010)). Emellett ugyancsak pozitív tendenciák figyelhetőek meg az indiai városok esetében is, azonban New York esetében sokkal szorosabb kapcsolat rajzolódik ki (átlagosan 3600 km-es „közeledés”), ami vélhetően a nagyarányú külföldi befektetéseknek (DIPPMC 2011) köszönhető, amelyek az országba érkeznek, valamint annak, hogy számos amerikai TNC telepítette háttérirodai (back office) tevékenységét az indiai városokba (Cairncross 1997, Pál, Boros 2010). London esetében is pozitív tendenciák figyelhetőek meg a gazdaságitávolság-értékekben az indiai szubkontinens városaival, de ezek mértéke kisebb a New York-inál (átlagosan $2500 \mathrm{~km}$-es).

A harmadik globális város, Tokió értékei nem tükrözik a másik két globális város esetében tapasztalt tendenciákat (5. ábra). A korábbi két várossal ellentétben a gazdaságitávolság-értékek Tokiónak szinte minden városkapcsolatában jóval meghaladják a földrajzi távolságok értékeit. Ennek nyomán a kontinensen belüli gazdaságossági küszöb vonala sem körvonalazódik egyértelműen, ami vélhetően arra vezethető vissza, hogy a másik két gazdasági magterülethez képest ez a régió eltérő homogenitással rendelkezik, így sokkal nagyobbak a fejlettségbeli különbségek, kisebb a fizetőképes kereslet, és a repülőjáratok sűrüsége is elmarad a nyugati régiókban tapasztaltaktól. Észak-Amerikában a keleti parti városok kisebb mértékben „távolodnak” (átlagosan 1800 km-rel), míg a nyugati parti vá- 


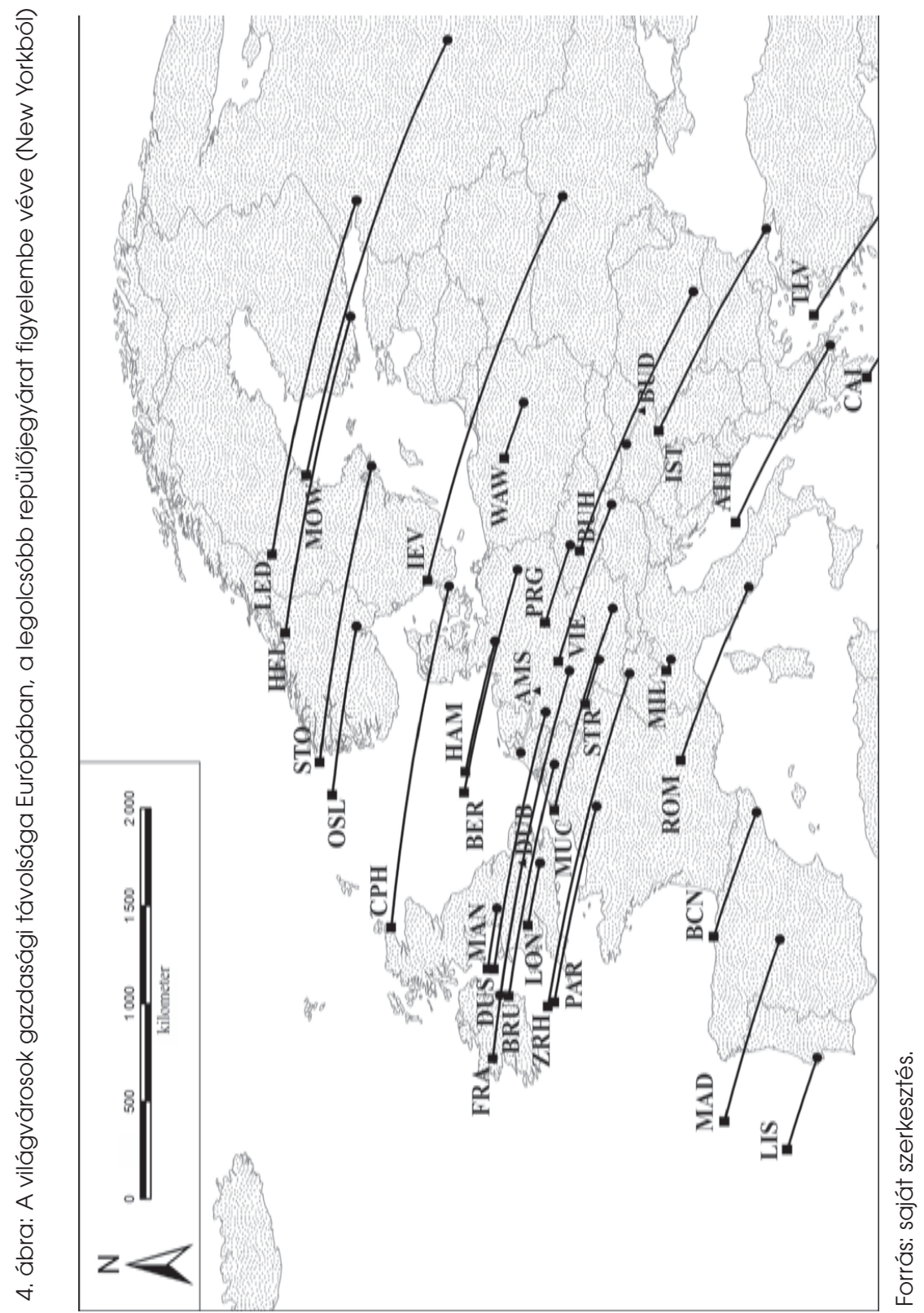




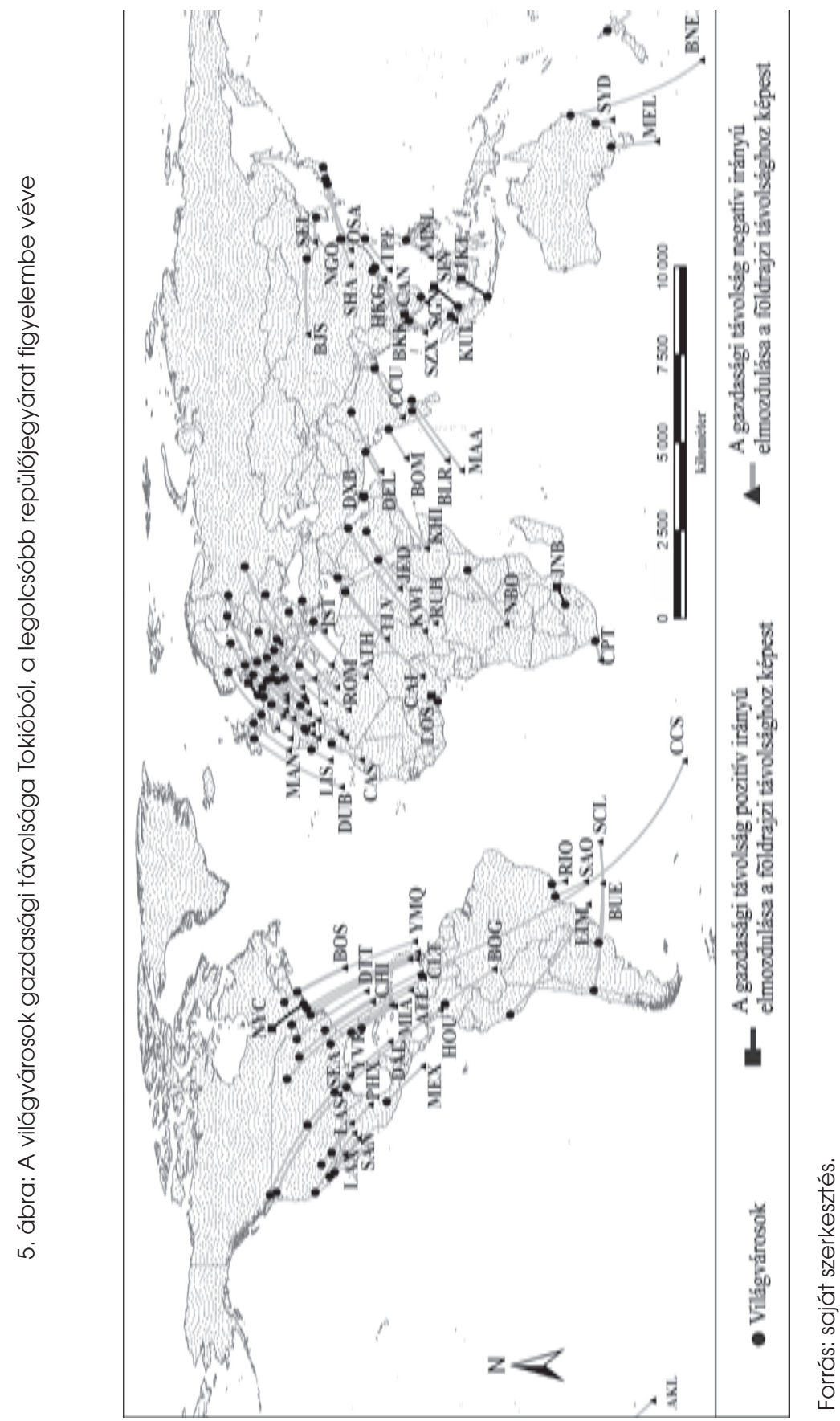


rosok esetében a gazdasági távolságok átlagosan 2800 km-rel meghaladják az adott városkapcsolatok közötti földrajzi távolságokat. Európában is hasonló tendencia mutatkozik, azonban a gazdaságitávolság-értékek közötti különbségek kisebbek, mint azt az észak-amerikai térségben tapasztalhattuk, és az átlagos „távolodás” mértéke 1500 km körül van.

A települési szintet megvizsgálva elmondhatjuk, hogy összesen nyolc város közeledik a japán fövároshoz. A New Yorknál a távol-keleti térséggel tapasztalt pozitív kapcsolatok Tokió esetében fordítva már nem érvényesülnek, hiszen az észak-amerikai kontinens világvárosai közül egyedül New York helyezkedik közelebb, mint földrajzi távolsága indokolná. Európában egyedül Amszterdam, míg a távol-keleti térségben Bangkok, Szingapúr és Jakarta gazdasági távolsága mutat pozitív értékeket.

\section{Az elérhetöség vizsgálata a globális városok és a világvárosok között}

A földrajzi kutatásokban a globális hálózati kapcsolatok és az elérhetőség előszeretettel vizsgált témakör. Ezen vizsgálatok döntő többsége azonban az észak-dél-megosztottságot hangsúlyozza (Taylor 2004, Zook, Brunn 2006), tehát a jobban elérhető, jobb kapcsolati értékekkel rendelkező városok a három gazdasági centrumban helyezkednek el, míg az alacsonyabb kapcsolati értékekkel rendelkező városok a déli féltekén találhatók. Vizsgálatunk során sokkal részletesebb képet akartunk mutatni a globális városok és a világvárosok közötti elérhetőségi értékekről. Ennek nyomán módosítottuk Duseknek és Szalkainak (2007) az izovonalas térképezés során használt módszerét, és az időtényezőt a térképezés során a repülőjegyárakra cseréltük, így a térképeinkről az olvasható le, hogy egy bizonyos összeg felhasználásával milyen messzire repülhetünk, vagyis hogyan alakul az egyes térségek elérhetősége a globális városokból.

London elérhetőségi térképein (6. ábra) jól látható, hogy az európai kontinens városainak többsége a 300 dolláros izovonalon belül található, és még a két orosz világváros is a 400 dolláros zónán belül helyezkedik el.

Az európai kontinenst az izovonalak „hozzávetőlegesen” koncentrikus körök formájában fedik le, míg a kontinenstől távolodva ezek a koncentrikus zónák megnyúlnak nyugati, illetve keleti irányban. A két gazdasági magtérség városai közül az észak-amerikai térség városai esetében körvonalazódnak a jobb elérhetőségi értékek, hiszen a keleti parti városok a 800 dolláros izovonalon belül találhatók, a kontinens belseje a 900 dolláros zónába esik, míg a nyugati parti városok is az 1000 dolláros izovonalon belül helyezkednek el. Ezzel szemben, ha keleti irányban utazunk, akkor a jó elérhetőségi értékek sokkal gyorsabban csökkennek - összehasonlításként a 800 dolláros zóna határa nyugaton kb. 5800 km-re fekszik Londontól, míg ugyanezen zóna határa 


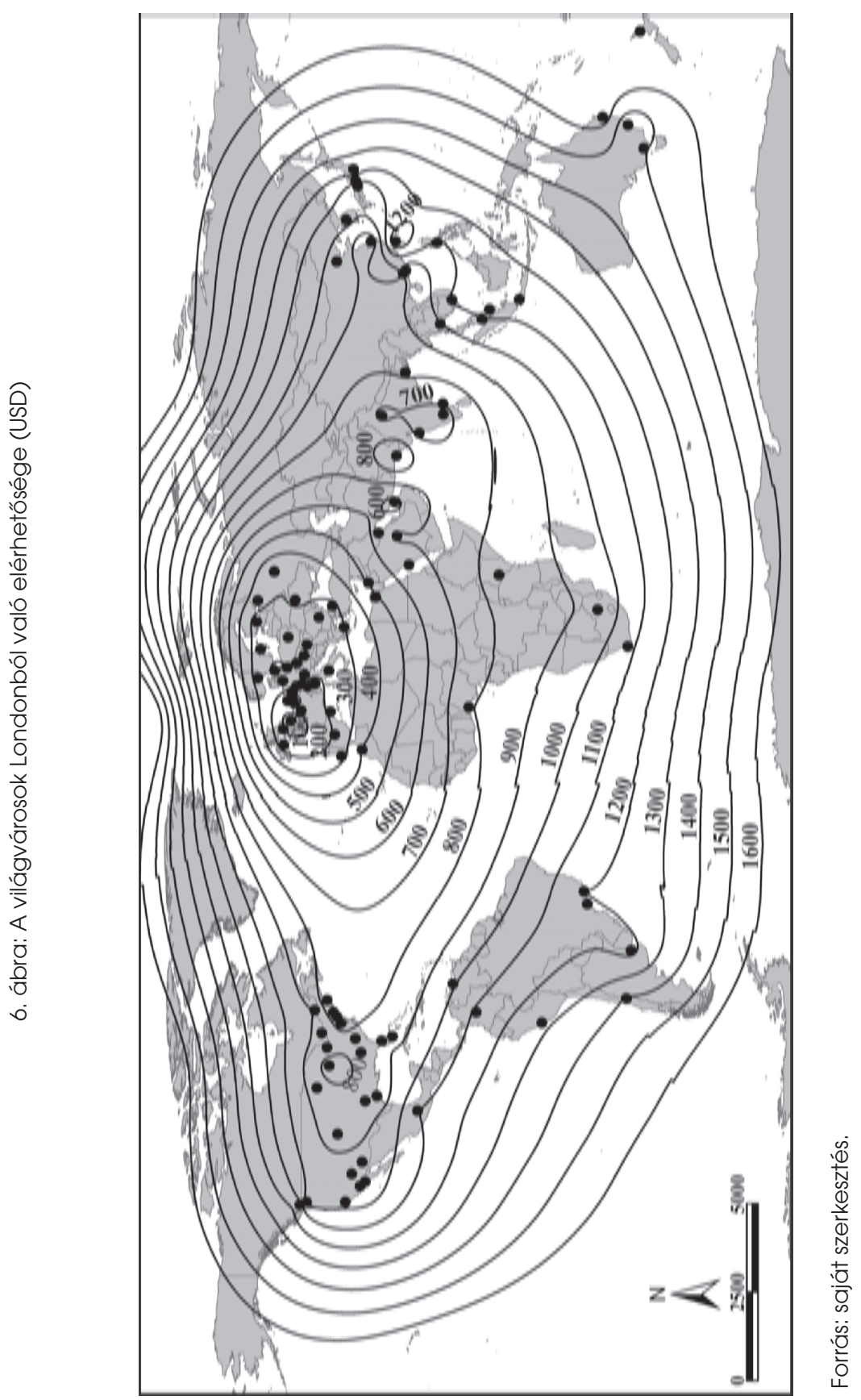


a keleti térségben Calcutta közelében húzódik kb. 8000 km-re Londontól -, és a térség sokkal összetettebb képet is mutat. Megfigyelhető, hogy például Dubaj és néhány indiai város (Mumbai, Bengaluru) térsége egy 600 dolláros szigetet alkot a 800 dolláros zónán belül, de ennek az ellenkezője is tapasztalható például Karacsi esetében.

A távol-keleti térség legfontosabb városai kívül esnek az 1000 dolláros izovonalon, így megállapíthatjuk, hogy az észak-amerikai városokhoz képest minimum egy elérhetőségi kategóriával rosszabb értékekkel rendelkeznek, de például a japán főváros, Tokió is már az 1200 dolláros zónán kívül helyezkedik el.

New York esetében (7. ábra) az elérhetőséget figyelembe véve sokkal összetettebb kép rajzolódik ki. Londonhoz hasonlóan az észak-amerikai kontinens városai itt is elérhetők a 400 dolláros zónán belül, azonban az elérhetőségi értékek a brit városnál tapasztalt kétirányú, lassú és bizonyos mértékben szabályos csökkenése itt csak egy (keleti) irányban figyelhető meg. Ennek következtében az európai kontinens gazdasági magtérsége a 800 dolláros izovonalon belül helyezkedik el, és a földrész összes városa elérhető az 1000 dolláros zónán belül, tehát elmondható, hogy a két világvárosból a másik térség világvárosai egyaránt elérhetőek maximum 1000 dolláros ráfordítással.

Londonnal ellentétben, New York esetében a távol-keleti térséggel már nem rajzolódik ki olyan szoros kapcsolat. Az egész távol-keleti térség, valamint Ausztrália és Afrika középső része aránylag homogén zónát alkot az 1400 dolláros izovonalon belül. Ebbe az egységes zónába a távol-keleti térség északi részén nyaláb formájában benyúlik egy rosszabb elérhetőségi értékkel rendelkező rész, amely olyan városokat foglal magába, mint Sanghaj, Szöul vagy Oszaka.

Londonnal összevetve itt is megfigyelhető néhány térségnek egy nagyobb kiterjedésű elérhetőségi zónán belüli pozitív vagy negatív kiemelkedése. Ez tapasztalható Dzsidda és Rijád térségében, amelyek magasabb elérhetőségi értékekkel rendelkeznek egy alacsonyabb elérhetőségi zónán belül, de pozitív jelenségek is megfigyelhetőek az indiai városok és Dubaj esetében - ahogyan azt Londonnál is tapasztalhattuk -, amelyek az 1400 dolláros zónán belül egy 1200 dolláros szigetet alkotnak.

Tokió elérhetőségi térképein (8. ábra) a másik két globális városhoz képest drasztikus mértékben csökkent a jó elérhetőségi mutatókkal rendelkező térségek aránya. A japán fővárosból már a távol-keleti térség is csak 800 dolláros izovonalon belül érhető el, szemben a másik két város esetében tapasztalt 400 dolláros zónával. Az egyes elérhetőségi zónák Tokió esetében hasonlítanak legjobban koncentrikus körökre, és az 1200 dolláros vonalig hozzávetőlegesen követik is ezt a formát.

Az egész európai térség az 1600 dolláros zónán belül elérhetö, azonban ebből is kiemelkedik a kontinensen belüli gazdasági magtérség, és egy 1200 dolláros szigetet alkot. Ezzel szemben az amerikai kontinens nem érhető el egységesen az 1600 dolláros zónán belül, hanem egy kisebb és egy nagyobb 


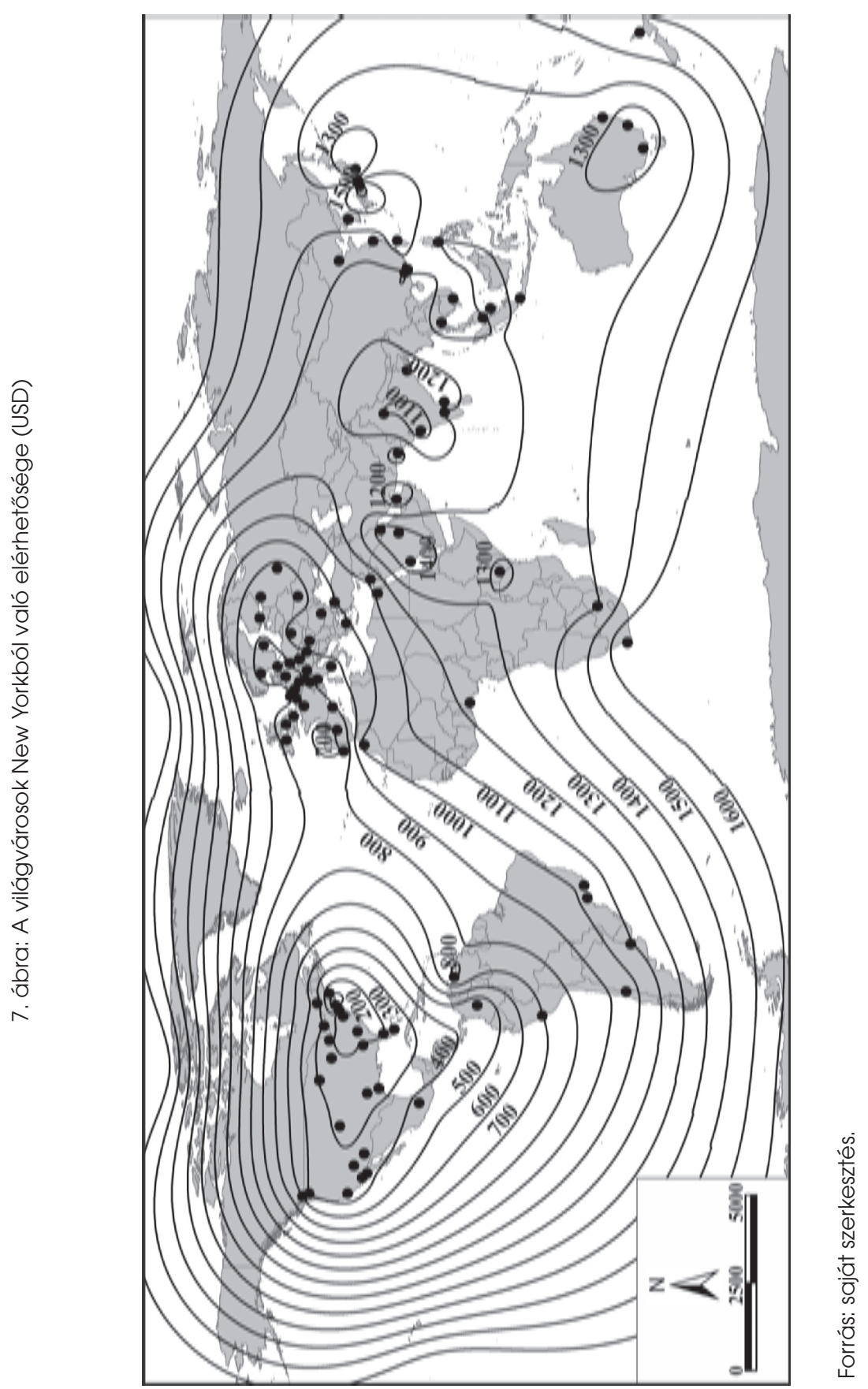




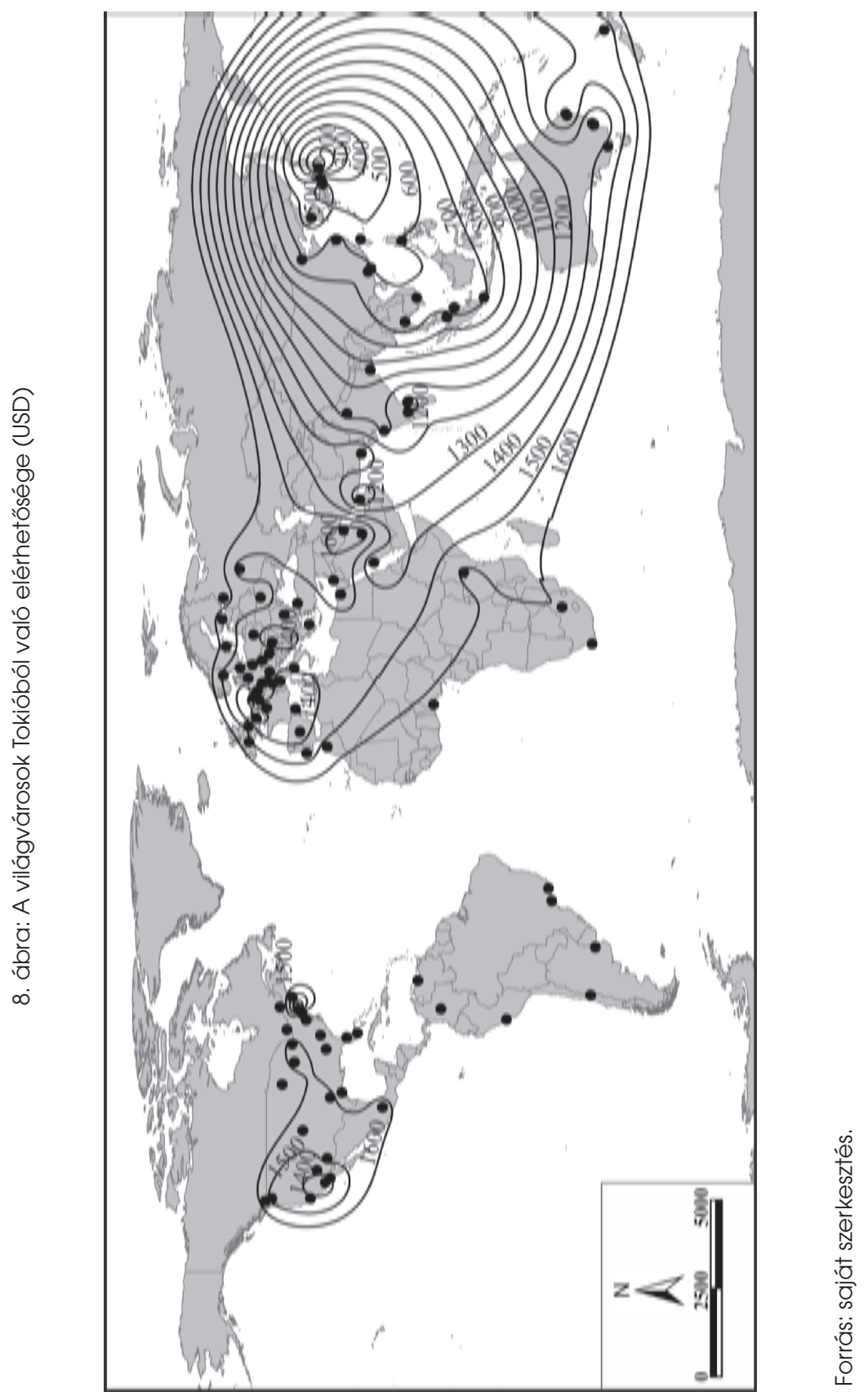


sziget található a kontinensen. A kisebb szigetet New York és szűk környezete alkotja, míg a nagyobb zónát a nyugati parti városok, amelyek a 1600 dolláros izovonalon belül helyezkednek el; közülük is kiemelkedik Los Angeles és szűk környezete, amely az 1200 dolláros izovonalon belül található.

\section{Összefoglalás}

Napjaink globalizációs folyamatai átalakították a távolságról alkotott elképzeléseinket. A közlekedési és távközlési infrastruktúrák fejlődésével a gazdasági távolság szerepe is egyre jobban felértékelődik. Ennek nyomán vizsgálatunk során a gazdasági távolság és az elérhetőség térképi megjelenítésére, módszertani aspektusainak kidolgozására helyeztük a hangsúlyt.

\section{Jegyzetek}

1 „A világváros (world city) elnevezést John Friedmann használja, és elsősorban a nagyvállalati központok elhelyezkedése alapján határozza meg azokat. A globális város (global city) elnevezés pedig Saskia Sassenhez kapcsolódik, aki hangsúlyozza a nagyvállalatokhoz kapcsolódó üzleti szolgáltatások fontosságát is, hiszen ezek biztosítják a vállalatok mindennapi müködésének hátterét" (Pál, Boros 2010). Mi különbséget teszünk a két fogalom között habár a hazai szakirodalom gyakran egymás szinonimájaként használja őket -, és globális városnak tekintjük a három kitüntetett várost (LON, NYC, TYO), míg világvárosoknak az 1 millió fönél népesebb városokat tartjuk, amelyek központi funkciójuknál fogva komoly gazdasági és politikai súllyal rendelkeznek (Kovács 2001), de egy hierarchiaszinttel a globális városok alatt helyezkednek el.

2 Az elemzésünkben a gazdasági távolságok meghatározásához használt repülőjegyárak komplexebb mérőszámoknak tekinthetőek, mint például a konténeres szállítás során használt szállítási költségek. A légi közlekedésben használt árképzési eljárás több függő és független változót vesz figyelembe, mint a többi szállítási mód, ennek nyomán a repülőjegyárak térben és időben is dinamikusabban változnak, mint a más szállítási módok esetében alkalmazott költségek. Ebből kiindulva pontosabb képet tudunk lefesteni két pont között fennálló gazdasági viszonyokról. Hiszen míg például a konténeres szállítás esetében az árak egy adott időintervallumon belül nem, vagy csak igen kis mértékben változnak (ugyanez igaz a városon belüli tömegközlekedésre is), addig a légi közlekedésben a kereslet és kínálat napi szinten változik. Mindezt nagyban befolyásolják az aktuális politikai és gazdasági döntések is, amelyek nyomán dinamikusabb árképzés és fluktuáló repülőjegyárak figyelhetőek meg. Ezért úgy véljük, hogy ebben az esetben a gazdasági távolság fogalma jobban tükrözi azt a mögöttes tartalmat, amivel a repülőjegyárakból számolt távolságok többet jelentenek a puszta költségtávolság fogalmával szemben.

3 Mesterségesen létrehozott változó, amelynek az értéke nulla vagy egy.

4 A kitüntetett városok listája: Európa: Amszterdam, Frankfurt, London, Madrid, Párizs, Róma; Ázsia: Bangkok, Hongkong, Peking, Szingapúr, Szöul, Tokió; Észak-Amerika: Atlanta, Chicago, Los Angeles, New York, Toronto, Washington D. C.

5 Például APTCO Airline Tariff Publishing Company, BACK Aviation O\&D-lux Origin - Destination Fare Data. 
6 A repülőjegyek minden esetben tartalmazták a repülőtéri adókat és illetékeket. A nemzetközi összehasonlíthatóság érdekében USD-ben számoltunk.

7 Az adatfelvételek során 18 kitüntetett város és a világvárosok közötti légi közlekedési adatokat kérdeztük le, így az adatbázisunkban összesen 1782 városkapcsolatra vonatkozó adat szerepelt. Így azonban bizonyos városkapcsolatok többször fordultak elő, ezért ezt a kettős „szerepeltetést” megszüntettük: ennek nyomán 1686 városkapcsolat segítségével végeztük a gazdasági távolságok meghatározását.

8 „Közeledő” városokon azt értjük, hogy a vizsgált városok gazdasági távolsága pozitív irányú elmozdulást mutat a földrajzi távolsághoz viszonyítva, tehát virtuálisan a térképeinken közelebb helyezkednek el a kiindulási városokhoz, míg a „távolodó” városok esetében pont az ellenkező tendenciák figyelhetők meg.

9 A gazdaságossági küszöb azt a határértéket jelenti, amely alatt a légitársaságok a jövedelmezőségük fenntartása érdekében nem tudnak utasokat szállítani.

10 Taylor (2004) ezeket a világvárosokat széles körü kapcsolatokkal rendelkező, azonban vezérlőfunkciót be nem töltő városokként (highly connceted non-command centres) definiálta, amelyek napjaink globalizációjának klasszikus kapuváros-funkcióit töltik be a nemzetközi és a regionális piacok felé.

\section{Melléklet}

A repülőtérkódok meghatározásánál a Nemzetközi Légi Szállítási Szövetség (International Air Transport Association - IATA) besorolását alkalmaztuk (IATA 2011), amely nem repülőterekként kódolja azokat, hanem a városoknak ad egy kódot, amelybe beletartozik az adott városban megtalálható összes repülötér.

\begin{tabular}{|c|c|c|c|c|c|c|c|}
\hline Amszterdam & AMS & Detroit & $\mathrm{DTT}$ & Lisszabon & LIS & Prága & PRG \\
\hline Athén & ATH & Dubaj & DXB & London & LON & Rijád & RUY \\
\hline Atlanta & ATL & Dublin & DUB & Los Angeles & LAX & Rio de Janeiro & RIO \\
\hline uckland & $\mathrm{AKL}$ & Düsseldorf & DUS & Madrid & MAD & Róma & ROM \\
\hline kok & BKK & Dzsidda & JED & Manchester & MAN & San Diego & SAN \\
\hline ona & $\mathrm{BCN}$ & Fokváros & CPT & Manila & MNL & Francisco & SFO \\
\hline yaluru & BLR & Frankfurt a. M. & FRA & Melbourne & MEL & Sanghaj & SHA \\
\hline in & BER & Hamburg & HAM & Mexikóváros & MEX & Santiago & $\mathrm{SCL}$ \\
\hline s & VIE & & HEL & Miami & MIA & Paulo & SAO \\
\hline & $B O G$ & Hongkong & HKG & Milánó & MIL & Seattle & SEA \\
\hline Bos & $\mathrm{BOS}$ & Houston & $\mathrm{HOU}$ & Minneapolis & MSP & Shenzhen & SZX \\
\hline ane & BNE & Ho Si Minh-város & SGN & Montreal & YMQ & kholm & STO \\
\hline & BRU & hbul & IST & Moszkva & MOW & gart & STR \\
\hline Dest & BUD & & JKT & bai & $\mathrm{BOM}$ & & SYD \\
\hline est & $\mathrm{BUH}$ & innesburg & JNB & hen & MUC & péter & LED \\
\hline s Aires & BUE & Kair & CAl & & NGO & yapúr & SIN \\
\hline tta & $\mathrm{CCU}$ & Kar & CAN & Nairobi & NBO & & SEL \\
\hline cas & CCS & & $\mathrm{KHI}$ & York & NYC & & TPE \\
\hline Casablanca & CAS & Kijev & IEV & Orlando & ORL & Tel Aviv-Jaffa & TLV \\
\hline Charlotte & CLT & Koppenhága & $\mathrm{CPH}$ & Oslo & OSL & Tokió & TYO \\
\hline Chicago & $\mathrm{CHI}$ & Kuala Lumpur & KUL & Oszaka & OSA & Toronto & YTO \\
\hline רnaj & MAA & Kuvait & KWI & Párizs & PAR & Vancouver & YVR \\
\hline & DAL & & LOS & Peking & BJS & Varsó & WAW \\
\hline & DEL & & LAS & Philadelphia & $\mathrm{PHL}$ & shingto & WAS \\
\hline Denver & DEN & & LIM & Pho & PHX & & ZRH \\
\hline
\end{tabular}




\section{Irodalom}

ACI - Airports Council International (2006): World Airport Traffic Report 2006. ACI World Headquarters, Geneva

ATAG - Air Transport Action Group (2008): The economic and social benefits of air transport 2008. Geneva

Beaverstock, J. V., Taylor, P. J. Smith, R. G. (1999): A roster of world cities. Cities, 16., 445-458.

Bilotkach, V. (2010): Reputation, search cost, and airfares. Journal of Air Transport Management, 16., 251-257.

Bilotkach, V., Pejcinovska, M. (2009): Distribution of airline tickets: a tale of two market structures. Kézirat

Burghouwt, G., van der Vlier, A. de Wit, J. (2007): Solving the lack of price data availability in (European) aviation economics? ATRS World Conference, Berkeley

Button, K. J., Vega, H. (2008): The effects of air transportation on the movement of labor, Geojournal, 71., 67-81.

Cairncross F. (1997): The death of distance - How the communication Revolution will change our lives. Harvard Business School Press, Boston

Cattan, N. (1995): Attractivity and internationalisation of major European cities: the example of air traffic, Urban Studies, 32., 303-312.

Cséfalvay Z. (2004): Globalizáció 1. 0. Nemzeti Tankönyvkiadó, Budapest

Csizmadia N., Csuták M. (2004): A légi közlekedés globális kontinensvándorlása. Turizmus Bulletin, 3., 47-52.

Derudder, B., Taylor, P. J., Ni, P., De Vos, A., Hoyler, M., Hanssens, H., Bassens, D., Huang, J., Witlox, F., Shen, W., Yang, X. (2010): Pathways of Change: Shifting Connectivities in the World City Network, 2000-08. Urban Studies, 47., 1861-1877.

Derudder, B., Witlox, F. (2005): An appraisal of the use of airline data in assessing the world city network: A research note on data. Urban Studies, 42., 2371-2388.

Derudder, B., Witlox, F. (2008): Mapping world city networks through airline flows: context, relevance, and problems. Journal of Transport Geography, 16., 205-312.

Derudder, B., Witlox, F., Faulconbridge, J., Beaverstock, J. (2008): Airline data for global city network research: reviewing and refining existing approaches. Geojournal, 71., 5-18.

Dicken, P. (2007): Global shift. Mapping the changing contours of the world economy. The Guilford Press, New York-London

DIPPMC (2011): Department of Industrial Policy \& Promotion Ministry of Commerce and Industry - Indiába érkező külföldi működőtőke befektetések. Internetről lekérdezve: http://dipp.nic.in/fdi_statistics/india_fdi_index.htm (Letöltve: 2011. 02. 23.)

Dobruszkes, F. (2006): An analysis of European low-cost airlines and their networks. Journal of Transport Geography, 14., 249-264.

Dobruszkes, F. (2009): New Europe, new low-cost air services. Journal of Transport Geography, 17., 423-432.

Dudás G., Pernyész P. (2011a): A világvárosok gazdasági távolságának és elérhetőségének összehasonlító vizsgálata légi közlekedési adatok felhasználásával. In: Bajmócy P., Józsa K. (szerk.): Geográfus Doktoranduszok XI. Országos Konferenciája. SZTE TTIK Gazdaság- és Társadalomföldrajz Tanszék, CD-kiadvány, Szeged

Dudás G., Pernyész P. (2011b): Shrinking distances? Mapping the economic distance of world cities using air traffic data. In Kovalcik, J., Muránsky, M., Rochovská, A. (eds.): Where do we go from there? Economic trends, social trajectories and policies of identities in post communist capitalism: collection of papers from the 4th Forum of $\mathrm{PhD}$ Students International Seminar: Bratislava, Slovak Republic, October 1-2, 2010., 32-44.

Dusek T., Szalkai G. (2006): Az időtér és a földrajzi tér összehasonlítása. Tér és Társadalom, 2., 47-63.

Dusek T., Szalkai G. (2007): Területi adatok ábrázolási lehetőségei speciális kartogrammokkal. Területi statisztika, 1., 3-19. 
GaWC - Globalization and World Cities Study Group and Network (2008): The world according to GAWC 2008. Internetről lekérdezve: http://www.lboro.ac.uk (Letöltve: 2010. 05. 31.)

Hadnagy E. (2011): Párizs elérhetőségének vizsgálata légiközlekedési adatok felhasználásával. Diplomamunka. Szegedi Tudományegyetem, Természettudományi és Informatikai Kar Gazdaság- és Társadalomföldrajz Tanszék

IATA (2011): (International Air Transport Association): Airport Codes, internetről lekérdezve: http://www.iata.org/ps/publications/Pages/code-search.aspx (Letöltve: 2011. 02. 23.)

Jónás I., Pál V., Szöllősy L., Vízvári A. (2010): Földrajz 10 - A világ változó társadalmi-gazdasági képe. Mozaik Kiadó, Szeged

Keeling, D. J. (1995): Transport and the world city paradigm. In: Knox, P., Taylor, P. (eds.): World cities in a world system. Cambridge University Press, Cambridge, 115-131.

Knowles, R. D. (2006): Transport shaping space: differential collapse in time-space. Journal of Transport Geography, 407-425.

Knox, P. L., Taylor, P. J. (1995): World cities in a world system. Cambridge University Press, Cambridge

Kovács Z. (2001): Társadalomföldrajzi kislexikon, Műszaki Kiadó, Budapest

Kunzmann, K. R. (1998): World city regions in Europe: structural change and future challenges. In: Lo, F. C., Yeung, Y. M. (eds.): Globalization and the World Large Cities. United Nations University Press, Tokyo, 37-75.

Lefebvre, H. (1991): The production of space. Basil Blackwell, Oxford

Massey, D. (1991): A global sense of place. Marxism Today, 24-29.

Matsumoto, H. (2004): International urban systems and air passenger and cargo flows: some calculations. Journal of Air Transport Management, 10., 241-249.

Matsumoto, H. (2007): International air network structures and air traffic density of world cities. Transportation Research Part E., 43., 269-282.

Móricz Á., Dudás G. (2010): Globális városhierarchia és elérhetőség - Budapest és a világvárosok légi kapcsolatának vizsgálata. A településföldrajz általános kérdései. Savaria University Press, Szombathely, 153-164.

Nemes Nagy J. (2009): Terek, helyek, régiók. A regionális tudomány alapjai. Akadémiai Kiadó, Budapest

Pain, K. (2009): London - The Pre-eminent Global City. GaWC Research Bulletin 328

Pál V., Boros L. (2010): A globális gazdaság ágazati és területi jellemzői. In: Mészáros R. (ed.): A globális gazdaság földrajzi dimenziói. Akadémiai Kiadó, Budapest, 123-171.

Pirie, G. H. (2009): Distance. In: Kitchin, R., Thrift, N. (eds.): International Encyclopedia of Human Geography, Volume Three, Elsevier, Amsterdam, 242-251.

Rimmer, P. J. (1998): Transport and telecommunication among world cities. In: Lo, F. C., Yeung, Y. M. (eds.): Globalization and the World Large Cities. United Nations University Press, Tokyo, 433-470.

Rodrigue, J-P., Comtois, D., Slack, B. (2006): The geography of transport systems. Routledge, London and New York

Sassen, S. (1991): The Global City. Princeton, NJ: Princeton University Press

Short, J. R., Kim, Y., Kuss. M., Wells, H. (1996): The dirty little secret of world city research: Data problems in comparative analysis. International Journal of Regional and Urban Research, 20, 697-717.

Smith, D. A., Timberlake, M. F. (2001): World City Network and Hierarchies, 1997-1997: An Empirical Analysis of Global Air Travel Links. American Behavioral Scientist, 44., 1656-1678.

Smith, D. A., Timberlake, M. F. (2002): Hierarchies of dominance among world cities: a network approach. In: Sassen, S. (ed.): Global Networks, Linked Cities. Routledge, London, 117-141.

Taaffe, E. J., Gauthier, H. L., O'Kelly, M. (1996): Geography of transportation, second ed. Prentice Hall, Englewood Cliffs, NJ.

Taylor, P. J. (2004): World City Network - A Global Urban Analysis. Routledge, London

Taylor, P. J. (2010): Competition and Cooperation Between Cities in Globalization. GaWC Research Bulletin 351 
Zook, M., Brunn, S. (2004): From podes to antipodes: New dimensions in mapping global time, cost, and distance. Specialist Workshop on Gobalization in the World-System: Mapping Change over Time. University of California, Riverside, 2004. február 7-8.

Zook, M., Brunn, S. (2006): From podes to antipodes: New dimensions in mapping global airline geographies. Annals of the Association of American Geographers, 3., 474-490. 


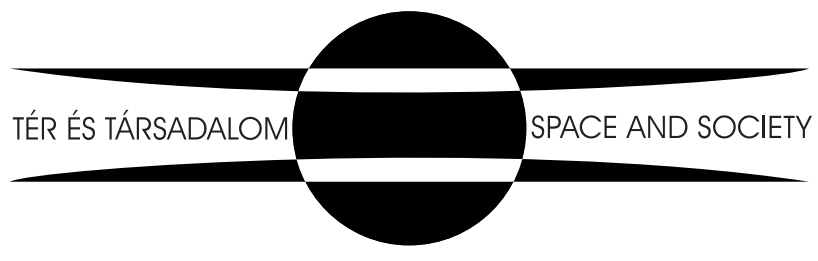

